\title{
Enhanced late-outgrowth circulating endothelial progenitor cell levels in rheumatoid arthritis and correlation with disease activity
}

\author{
Vanina Jodon de Villeroché1, Jérome Avouac1,2, Aurélie Ponceau1', Barbara Ruiz1, André Kahan², Catherine Boileau1,3, \\ Georges Uzan ${ }^{4}$ and Yannick Allanore*1,2
}

\begin{abstract}
Introduction: Angiogenesis and vasculogenesis are critical in rheumatoid arthritis (RA) as they could be a key issue for chronic synovitis. Contradictory results have been published regarding circulating endothelial progenitor cells (EPCs) in RA. We herein investigated late outgrowth EPC sub-population using recent recommendations in patients with RA and healthy controls.

Methods: EPCs, defined as Lin-/7AAD-/CD34+/CD133+/VEGFR-2+ cells, were quantified by flow cytometry in peripheral blood mononuclear cells (PBMCs) from 59 RA patients (mean age: $54 \pm 15$ years, disease duration: $16 \pm 11$ years) and 36 controls (mean age: $53 \pm 19$ years) free of cardiovascular events and of cardiovascular risk factors. Concomitantly, late outgrowth endothelial cell colonies derived from culture of PBMCs were analyzed by colonyforming units (CFUs).

Results: RA patients displayed higher circulating EPC counts than controls (median 112 [27 to 588] vs. 60 [5 to 275]) per million Lin- mononuclear cells; $P=0.0007$ ). The number of circulating EPCs positively correlated with disease activity reflected by DAS-28 score $(r=0.43 ; P=0.0028)$ and lower counts were found in RA patients fulfilling remission criteria ( $P$ $=0.0069$ ). Furthermore, late outgrowth CFU number was increased in RA patients compared to controls. In RA, there was no association between the number of EPCs and serum markers of inflammation or endothelial injury or synovitis.

Conclusions: Our data, based on a well characterized definition of late outgrowth EPCs, demonstrate enhanced levels in RA and relationship with disease activity. This supports the contribution of vasculogenesis in the inflammatory articular process that occurs in RA by mobilization of EPCS.
\end{abstract}

\section{Introduction}

Rheumatoid arthritis (RA) is a chronic and destructive inflammatory disease affecting the joints. RA is now well known to be associated with striking neovascularization developed in inflammatory joints [1]. Indeed, angiogenesis, leading to an increased number of synovial vessels through local endothelial cells, is a cornerstone of synovial hyperplasia occurring in RA. Disturbances in endothelial cell turnover and apoptosis as well as in angiogenic factors such as vascular endothelial growth factor (VEGF) have been

\footnotetext{
* Correspondence: yannick.allanore@cch.aphp.fr

${ }^{1}$ INSERM U781, Paris Descartes University, Necker Hospital, 149 Rue de Sevres, 75015 Paris, France
}

See related editorial by Szekanecz and Koch, http://arthritis-research.com/ content/12/2/110 reported in RA synovium [2,3]. However, despite the abundant synovial vasculature, there are areas of synovial hypoxia contributing to synovial and cartilage damage $[4,5]$. Hypoxia is highly suggested to activate the angiogenic cascade, thereby contributing to the perpetuation of RA synovitis [6].

In addition to angiogenesis issued from resident cells, cells derived from bone marrow and named circulating endothelial progenitor cells (EPCs) are able to promote new blood vessel formation (vasculogenesis) and may therefore contribute to RA synovitis [7].

EPCs were originally identified by (a) the expression of markers shared with hematopoietic stem cells such as CD34 and CD133, (b) specific endothelial cell markers such as KDR (vascular endothelial growth factor receptor-2 
[VEGFR-2] or kinase-insert domain receptor), and (c) their capacity to differentiate into functional endothelial cells [810]. However, there is no consensus on the precise definition of EPCs [11]. Evidence showed that there is more than one endothelial progeny, monocytic versus hemangioblastic, within the circulating blood, and two distinct cell types of EPCs are currently recognized according to their growth characteristics and morphological appearance: early-outgrowth EPCs and late-outgrowth EPCs [7,12].

In the currently available human studies, variations in the level of circulating EPCs were reported in different diseases affecting the vascular system and were suggested to be a biomarker for vascular function and tumor progression $[13,14]$. In the field of RA, contradictory results have been reported. Indeed, some studies suggested a lower circulating EPC number in RA patients compared with controls $[9,10]$, but conversely, some others reported higher values [15], and finally some other reports did not find any difference $[8,16]$. Several studies have shown an increase of EPCs within the RA synovial tissue $[17,18]$.

Altogether, these observations underline the difficulty of accurately quantifying EPC populations. The major issue is the identification of the different types of circulating endothelial cells (CECs) issued respectively from the vessel wall or from bone marrow progenitors. The use of accurate methods allowing the detection of rare events by flow cytometry is thus critical. Within this context, our group contributed to recommendations aiming at the improvement of EPC detection and characterization [19]. In line with these latter recommendations and our background in systemic sclerosis [20], we focused on late-outgrowth EPCs that represent the progenitors with the more genuine endothelial properties. In parallel to EPCs, CECs detached from vessel walls (CECs) may also be a relevant biomarker of vascular disease. We hypothesized that coupled raised levels of these two populations may reflect the vascular status of the disease and thus represent innovative biomarkers. Therefore, our aims were (a) to enumerate EPCs and lateoutgrowth endothelial colony formation in RA patients and controls, (b) to assess correlations between EPC counts, CEC counts, and RA activity, and (c) to correlate EPC and CEC counts with levels of serum markers of synovitis or endothelial injury.

\section{Materials and methods Patients}

The study involved 59 RA patients (54 females; mean age of $54 \pm 15$ years) fulfilling the RA American College of Rheumatology criteria [21]. RA patients were consecutively enrolled during a 6-month period regardless of disease activity and underwent a routine clinical examination that included the calculation of 28-joint disease activity score (DAS-28). The patients' characteristics are summarized in Table 1. Ongoing biologic therapies included tumor
Table 1: Rheumatoid arthritis study population

\begin{tabular}{|c|c|}
\hline $\begin{array}{l}\text { Laboratory and clinical } \\
\text { data }\end{array}$ & RA patients $(n=59)$ \\
\hline $\begin{array}{l}\text { Disease duration in days, } \\
\text { mean } \pm S D\end{array}$ & $16 \pm 11$ \\
\hline $\begin{array}{l}\text { Erosive RA, number } \\
\text { (percentage) }\end{array}$ & $54(92)$ \\
\hline $\begin{array}{l}\text { Positive rheumatoid factor, } \\
>10 \text { IU, ELISA, number } \\
\text { (percentage) }\end{array}$ & $52(88)$ \\
\hline $\begin{array}{l}\text { Positive anti-CCP antibodies, } \\
>10 \text { IU, ELISA, number } \\
\text { (percentage) }\end{array}$ & $52(88)$ \\
\hline $\begin{array}{l}\text { ESR in } \mathrm{mm} / \text { hour, mean } \pm \mathrm{SD} \text {; } \\
\mathrm{ESR}>28, \text { number } \\
\text { (percentage) }\end{array}$ & $28 \pm 21 ; 35(59)$ \\
\hline $\begin{array}{l}C R P \text { in } \mathrm{mg} / \mathrm{dL} \text {, mean } \pm \mathrm{SD} ; \\
\mathrm{CRP}>15, \text { number } \\
\text { (percentage) }\end{array}$ & $25 \pm 41 ; 23(39)$ \\
\hline DAS-28, mean $\pm S D$ & $4.36 \pm 1.7$ \\
\hline $\begin{array}{l}\text { DAS-28<2.6, number } \\
\text { (percentage) }\end{array}$ & $11(19)$ \\
\hline $\begin{array}{l}2.6<\text { DAS- } 28<5.1 \\
\text { number (percentage) }\end{array}$ & $21(35)$ \\
\hline $\begin{array}{l}\text { DAS-28 }>5.1, \text { number } \\
\text { (percentage) }\end{array}$ & $27(46)$ \\
\hline $\begin{array}{l}\text { Methotrexate, number } \\
\text { (percentage) }\end{array}$ & $49(83)$ \\
\hline $\begin{array}{l}\text { Low dose of prednisone, } \leq 10 \\
\text { mg/day, number } \\
\text { (percentage) }\end{array}$ & $54(92)$ \\
\hline $\begin{array}{l}\text { Anti-tumor necrosis factor } \\
\text { agents, number (percentage) }\end{array}$ & $11(17)$ \\
\hline $\begin{array}{l}\text { Anti-CD20 agents, number } \\
\text { (percentage) }\end{array}$ & $12(20)$ \\
\hline
\end{tabular}

necrosis factor (TNF) blockers (etanercept, adalimumab, or infliximab) in 11 patients and anti-CD20 (rituximab) in 12 patients. Thirty-six healthy volunteers (26 females; mean age of $53 \pm 19$ years) coming from our first study served as controls [20]. Exclusion criteria for all subjects were cardiovascular events and conventional cardiovascular risk factors (diabetes, hypertension, and past medical history of coronary artery disease and smoking) except for three RA patients with controlled systemic hypertension. None of the patients had been treated previously with statins, a drug 
known to be associated with increased EPC levels [22,23]. All patients and volunteers gave informed consent for all procedures, which were carried out with local ethics committee approval Comité de Protection des Personnes, Ile de France III (CPPP IDF III).

\section{Flow cytometry quantification}

EPCs were quantified by fluorescence-activated cell sorting (FACS) as previously described [20]. Briefly, peripheral blood mononuclear cells (PBMCs) were first depleted of positive lineage mononuclear cells $\left(\mathrm{CD} 2^{+}, \mathrm{CD}^{+}, \mathrm{CD}^{4} 4^{+}\right.$, $\mathrm{CD}_{16}{ }^{+}, \mathrm{CD} 19^{+}, \mathrm{CD} 24^{+}, \mathrm{CD}^{+} 6^{+}$, and $\mathrm{CD}_{66 b^{+}}$cells) by human progenitor cell enrichment cocktail (RosetteSep ${ }^{\circledR}$; StemCell Technologies, Vancouver, BC, Canada), and secondly subjected to triple-labelling with anti-CD133-phycoerythrin (PE) (Miltenyi Biotec, Paris, France), antiVEGFR-2 (KDR)-allophycocyanin (APC) (R\&D Systems, Minneapolis, MN, USA), and anti-CD34 or anti-CD105fluorescein isothiocyanate (FITC) (BD Biosciences, Le Pont de Claix, France) antibodies. A preincubation of an FcR-blocking reagent (Miltenyi Biotec) was performed to inhibit non-specific binding, and identical IgG isotypes served as negative controls. Third, viable PBMCs were discriminated by 7-aminoactinomycin D (7AAD) labelling. The EPC and CEC populations were finally identified as $\mathrm{Lin}^{-} / 7 \mathrm{AAD}^{-} / \mathrm{CD}_{3} 4^{+} / \mathrm{CD} 133^{+} / \mathrm{VEGFR}-2^{+}$cells and $\mathrm{Lin}^{-} /$ 7AAD $/ \mathrm{CD} 105^{+} / \mathrm{CD} 133-/ \mathrm{VEGFR}-2^{+}$cells, respectively. At least 500,000 events were analyzed, and results were expressed as the number of EPCs or CECs per million Lin mononuclear cells.

\section{Endothelial progenitor cell quantification by late- outgrowth colony-forming unit assay}

In $53 \mathrm{RA}$ patients and 35 controls with FACS quantification, we used a method of culture suitable for isolating lateoutgrowth EPC-derived colonies [20]. The blood mononuclear cell fraction was collected by Ficoll (Pancoll, Dutcher, France) density gradient centrifugation and was resuspended in endothelial growth medium (EGM-2) (Lonza, Verviers, Belgium). Cells were then seeded on collagenprecoated 12-well plates (BD Biosciences) at $2 \times 10^{7}$ cells per well and stored at $37^{\circ} \mathrm{C}$ and $5 \% \mathrm{CO}_{2}$. After 24 hours of culture, adherent cells were washed once with phosphatebuffered saline $1 \mathrm{x}$ and cultured in EGM-2 with daily changes until the quantification. Colonies of endothelial cells appeared between 9 and 26 days of culture and were identified as well-circumscribed monolayers of cells with a cobblestone appearance. EPC colonies were counted visually under an inverted microscope (Olympus, Paris, France).

\section{Enzyme-linked immunosorbent assays}

In a random subgroup of 49 patients with RA and 10 healthy controls, levels of serum soluble vascular cell adhe- sion molecule-1 (sVCAM), stromal-derived factor-1 (SDF1), human cartilage glycoprotein-39 (YKL-40), and cartilage oligomeric matrix protein (COMP) -- markers of endothelial injury, progenitor mobilization, synovitis, and synovitis, respectively -- were measured by enzyme-linked immunosorbent assay (R\&D Systems; Kamiya Biomedical Company, Seattle, WA, USA; and Quidel Corporation, San Diego, CA, USA) in accordance with the manufacturers' instructions.

\section{Data analysis}

All data are presented as median (range) unless otherwise stated. Comparisons were performed by non-parametric Mann-Whitney, Kruskal-Wallis, or Spearman rank correlation ( $r$ ) tests, when appropriate. The chi-square test was used to compare categorical variables. $P$ values are twotailed, and $P$ values of not more than 0.05 were considered statistically significant.

\section{Results}

Endothelial progenitor cell and circulating endothelial cell levels in rheumatoid arthritis

EPC level (Lin-/7AAD-/CD34+/CD133+/VEGFR-2 ${ }^{+}$) was significantly higher in RA patients than in controls (112 [27 to 588] versus 60 [5 to 275] EPCs; $P=0.0007$ ) (Table 2 and Figure 1a). The two Lin-/7AAD-/CD133+/VEGFR-2 ${ }^{+}$and Lin-/7AAD-/CD34+/VEGFR-2+ ${ }^{+}$subpopulations were also significantly higher in RA patients (Table 2). The CEC population (Lin-/7AAD-/CD105+/CD133-/VEGFR-2 ${ }^{+}$cells) was increased in RA patients compared with controls, although this did not reach statistical significance (Table 2 and Figure 1b). The CEC and EPC levels in RA patients as well as in controls were correlated $(r=0.43$ and $0.74, P=$ 0.003 and 0.0015 , respectively) (Figure 2).

\section{Association between endothelial progenitor cell levels and disease activity}

In RA patients, EPC levels correlated with DAS-28 ( $r=$ $0.43, P=0.003$, Spearman test) (Figure 3a). In addition, EPC levels were significantly decreased in patients fulfilling DAS-28 remission criteria when compared with moderate $(2.6<$ DAS-28 $<5.1)$ or high (DAS-28 $>5.1)$ activities $(P=0.007$, Kruskal-Wallis test) (Figure 3b). No association was found between EPC levels and high values of erythrocyte sedimentation rate $(\mathrm{ESR})(>28)(P=0.9)$ or between EPC levels and high values of C-reactive protein $(>15)(P=$ $0.7)$. Swollen joint counts did not correlate with EPC values $(r=0.23, P=0.99)$. There was no association between EPC number and age, disease duration, and other disease features, including treatments (low doses of corticosteroids and methotrexate). In regard to biologic therapy, patients receiving TNF blockers or anti-CD20 did not have different EPC levels (median [range] 88 [27 to 529], $P=0.9922$ and 83.5 [33 to 345 ], $P=0.1906$, respectively). Likewise, CEC 
(a)

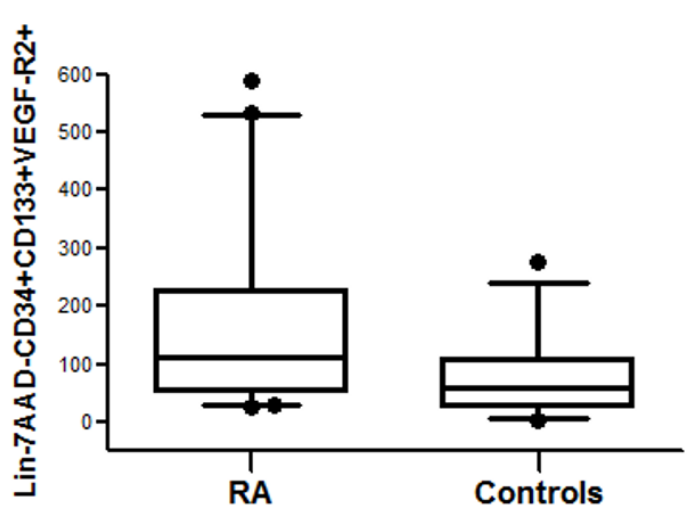

(b)

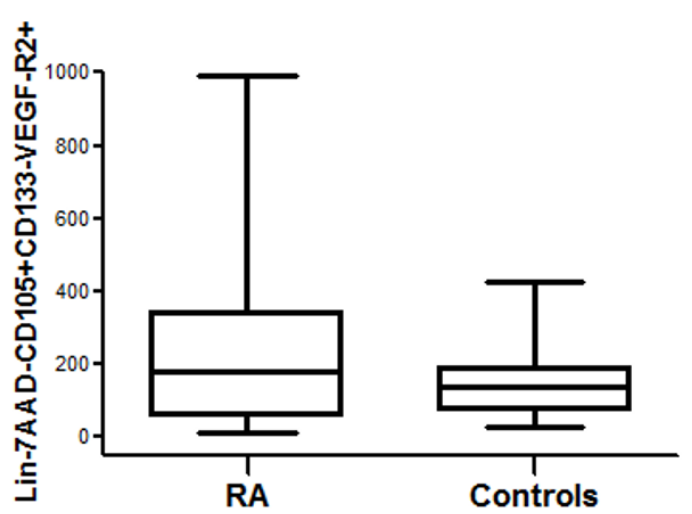

Figure 1 Endothelial progenitor cell (EPC) and circulating endothelial cell (CEC) levels in rheumatoid arthritis (RA) patients compared with controls (cells per 106 lineage-negative [Lin-] mononuclear cells). (a) Higher EPC levels (Lin-7AAD-CD34+CD133+VEGFR-2+) in RA patients $(n=59)$ than in controls $(n=36)(P<0.001)$. (b) No significant difference between CEC levels (Lin-7AAD-CD105+CD133-VEGFR-2+) in RA patients $(n=59)$ and controls $(n=15)$. 7AAD, 7-aminoactinomycin D; VEGFR-2, vascular endothelial growth factor receptor-2.

levels did not correlate with RA characteristics or treatments.

\section{Number of late-outgrowth endothelial progenitor cell colony-forming units in rheumatoid arthritis}

Endothelial colony formation has previously been used as an alternative method to detect endothelial progenitors in PBMCs [20]. CFU assays were performed in association with FACS quantification in 53 RA patients and 35 controls. EPC-CFUs appeared at the ninth day of PBMC culture at the earliest and were confirmed by a typical morphology of a well-delineated colony of cells with a cobblestone appearance (Figure 4a). The percentage of RA patients displaying EPC colony formation was significantly higher than that of controls $(74 \%$ versus $57 \% ; P=0.029)$ in accordance with their higher EPC levels (118.5 [29 to 588] versus 84 [19 to 275]; $P=0.049$ ). Furthermore, comparison of the mean number of EPC-CFUs measured in RA patients and controls revealed an increase in CFU number in RA patients $(3.4 \pm 0.7$ versus $2 \pm 0.5 ; P=0.048)$ (Figure $4 b)$. In the RA population, CFU numbers correlated with none of RA characteristics or treatments.

\section{Lack of association between serum markers and endothelial progenitor cell levels}

Different serum markers -- including sVCAM (677 [294 to 2,624] versus 512 [371 to 738] ng/mL; $P=0.018)$, YKL-40 (88 [24 to 256$]$ versus 50 [15 to 59$] \mathrm{ng} / \mathrm{mL} ; P=0.0029$ ), and COMP (2.4 [1.2 to 4.4 ] versus 1.3 [0.8 to 1.5$] \mu \mathrm{g} / \mathrm{mL} ; P$ $<0.0001)$-- were found to be significantly increased in RA patients as compared with healthy controls. There was no significant difference for SDF-1 concentration (3,690 [73 to $6,973]$ versus 3,562 [1,540 to 6,451$] \mathrm{pg} / \mathrm{mL})$. However, values of EPCs in RA patients were unrelated to any of the above serum markers. Also, CEC levels were not linked with serum markers of synovitis but were significantly higher in RA patients with a high sVCAM level $(>1,000 \mathrm{ng} /$ $\mathrm{mL} ; P=0.0035)$. (a)

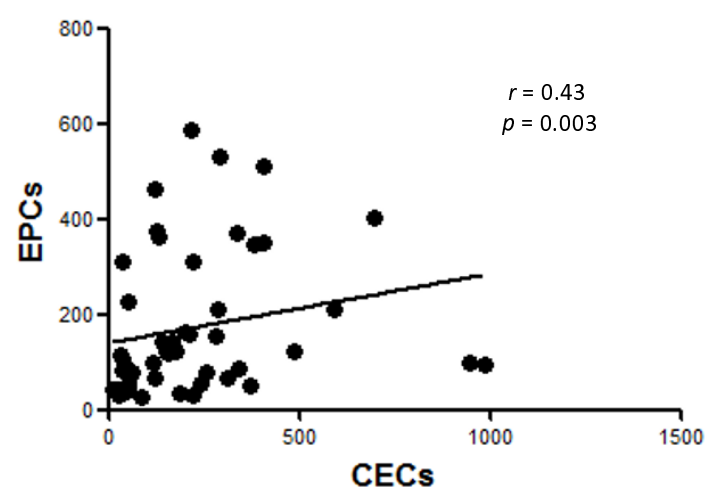

(b)

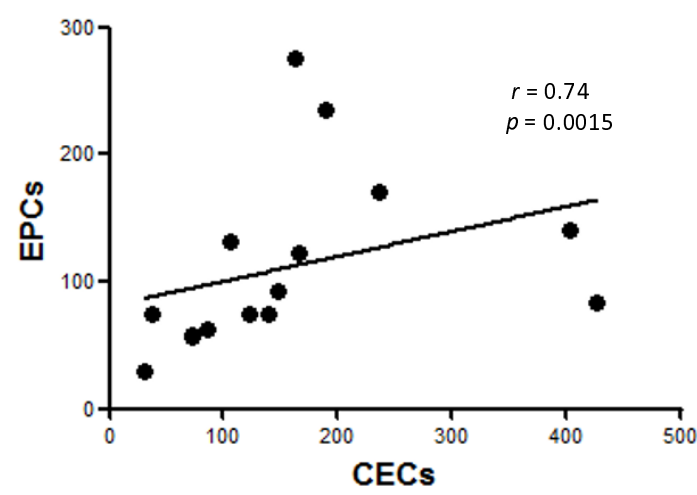

Figure 2 Positive correlation between endothelial progenitor cell (EPC) counts and circulating endothelial cell (CEC) counts (cells per $10^{6}$ lineage-negative mononuclear cells). (a) Patients with rheumatoid arthritis. (b) Controls. Correlation coefficient $r$ and $P$ values are indicated. 
Table 2: Absolute number of stem cells and circulating endothelial progenitor cells in peripheral blood (cells per $10^{6}$ lineage-negative mononuclear cells)

\begin{tabular}{|c|c|c|c|}
\hline $\begin{array}{c}\text { Cells per } 106 \text { Lin- } \\
\text { mononuclear cells }\end{array}$ & RA patients $(n=59)$ & Controls $(n=36)$ & P value \\
\hline Lin-/7AAD-/CD34+/CD133+ & & & 0.0002 \\
\hline Median (range) & $2,484(213-26,613)$ & $1,068(123-2,270)$ & \\
\hline $25 \%-75 \%$ percentile & $1,141-5,943$ & $610.5-1,575$ & \\
\hline Lin-/7AAD-/CD34+/VEGFR-2+ & & & 0.0026 \\
\hline Median (range) & $259(27-588)$ & $103(11-1,105)$ & \\
\hline $25 \%-75 \%$ percentile & $124-493$ & $49.75-193.8$ & \\
\hline Lin-/7AAD-/CD133+/VEGFR-2 $^{+}$ & & & 0.0276 \\
\hline Median (range) & $151(45-964)$ & $125(25-555)$ & \\
\hline $25 \%-75 \%$ percentile & $93-387$ & $99.25-192.8$ & \\
\hline $\begin{array}{l}\text { Lin-/7AAD-/CD34+/CD133+/ } \\
\text { VEGFR-2+(EPCs) }\end{array}$ & & & 0.0007 \\
\hline Median (range) & $112(27-588)$ & $60(5-275)$ & \\
\hline $25 \%-75 \%$ percentile & $53-227$ & $26-109.8$ & \\
\hline $\begin{array}{l}\text { Lin-/7AAD-/CD105+/CD133-/ } \\
\text { VEGFR-2+(CECs) }\end{array}$ & & & 0.1727 \\
\hline Median (range) & $173(12-989)$ & $139(30-426)^{a}$ & \\
\hline $25 \%-75 \%$ percentile & $57-341$ & $73-189$ & \\
\hline $\begin{array}{l}\text { Ratio EPCs/CECs, median } \\
\text { (range) }\end{array}$ & $1(0.07-4.28)$ & $1(0.2-2.02)^{\mathrm{a}}$ & 0.3946 \\
\hline
\end{tabular}

aCirculating endothelial cell (CEC) number has been evaluated in 15 healthy controls. 7AAD, 7-aminoactinomycin D; DAS-28, 28-joint disease activity score; EPC, endothelial progenitor cell; Lin-, lineage-negative; RA, rheumatoid arthritis; VEGFR-2, vascular endothelial growth factor receptor-2.

\section{Discussion}

Our results obtained by using a well-characterized definition of late-outgrowth EPCs in a relatively large number of patients show enhanced levels of this cell population and relationships with RA disease activity. Available data have reported conflicting results about the EPC counts in this inflammatory condition. Several methodological issues could explain such discrepancies. We herein followed recent recommendations and used a previously validated method for late-outgrowth EPC enumeration [20].

The quantification of EPCs by flow cytometry first requires enrichment techniques to select a correct number of this scarce population and a specific marker combination to select the subpopulation of hemangioblastic EPCs. In culture, these 'true' angioblast-like EPCs are represented by cells that enable late outgrowth with higher proliferative potential, while endothelial cell colonies that appear early might more preferentially originate from monocytes or CECs $[11,24]$. In the study herein, we excluded the monocytic EPC subpopulation from the quantification and thus selected hemangioblastic EPCs by the lineage-positive cell depletion including $\mathrm{CD} 14^{+}$cells. We also extended the circulating EPC definition with an additional marker of viability to select non-apoptotic cells. One may suggest that the several steps required by our technique may induce procedural loss of progenitors which are prone to undergo apoptosis. However, the controlled design of our study limits this potential bias but this will need additional work. In parallel, EPC counts were also determined by the selection in culture of the late-outgrowth EPCs according to the delays before their appearance.

None of the previous studies that reported EPC levels in RA patients was based on these methods. The previous data quantified, conversely to our study, circulating EPCs in whole blood with only three surface markers (CD34/ CD133/VEGFR-2) [8-10,16]. These authors also assessed EPC-CFU numbers, focusing on the 'early outgrowth' subpopulation and finding or not finding results consistent with those of flow cytometry quantification. These methodological differences may account for the discrepancy with regard 
(a)

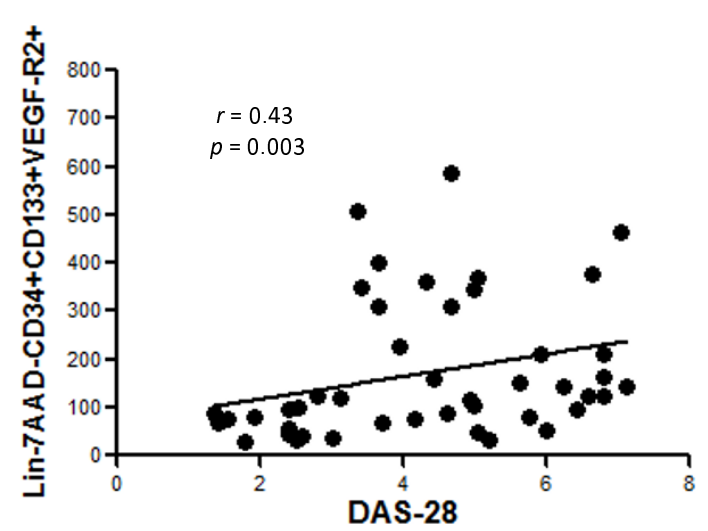

(b)

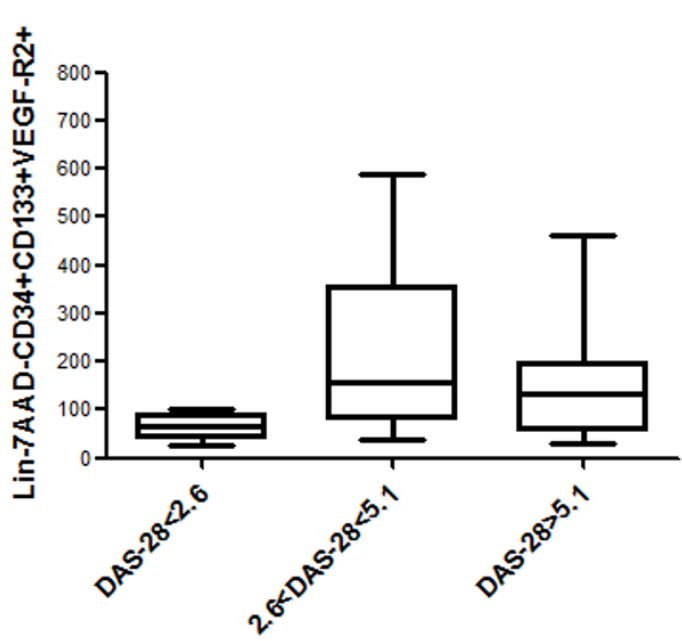

Figure 3 Associations of endothelial progenitor cell (EPC) levels in rheumatoid arthritis (RA) with disease activity. Correlation between EPC counts and disease activity (a) and association of lower EPC levels in different groups of RA patients according to disease activity score $(P<0.01)(\mathbf{b})$. 7AAD, 7-aminoactinomycin D; DAS-28, 28-joint disease activity score; Lin-, lineage-negative; VEGFR-2, vascular endothelial growth factor receptor-2.

to our results. Indeed, differences between the various EPC studies may not relate to the characteristics of the RA population enrolled. Our population of RA patients, issued from consecutive inclusions, did not display differences with other studies based on criteria known to modulate EPC levels -- such as age (mean of 53 to 59 years) and frequency of use of methotrexate or low doses of corticosteroids -- or on the choice to exclude patients with previous cardiovascular events [25-27]. In addition, it is noteworthy that EPC counts did not differ according to the use of biologics, although the cross-sectional design limits the analysis of the influence of such therapies in our RA patients. The only specificity of our RA patients may be the relatively long disease duration in comparison with other works. Neverthe- less, disease duration was never reported to be associated with EPC levels and thus may not account for our findings. We excluded RA patients with cardiovascular risk factors in order to rule out the bias of the specific effects of atheroma on EPC counts and thus to focus on relationships between disease activity and EPC counts as this has been done in many previous studies $[9,10]$. One may suggest that this may have introduced a selection bias and the use of this exclusion criterion may have obscured a negative influence of cardiovascular risk factors on EPC counts.

We herein provide the demonstration of the identification of the late-outgrowth subset by the association between circulating cell counts and culture isolations. Indeed, two different subpopulations of EPCs, namely early and late EPCs, (a)

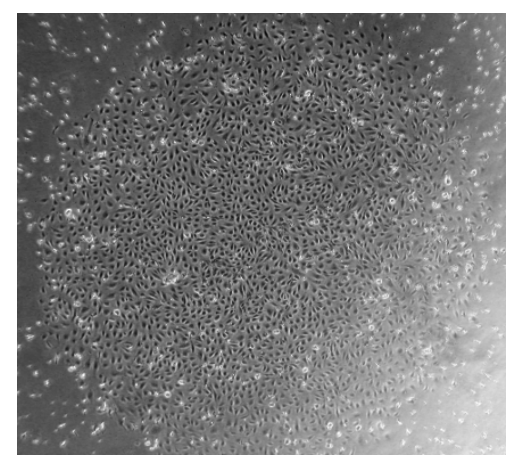

(b)

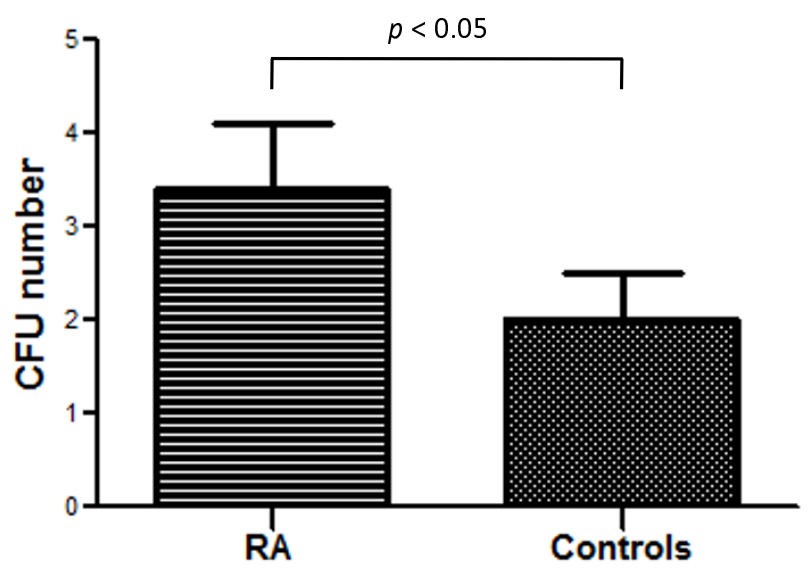

Figure 4 Late-outgrowth endothelial progenitor cell colony-forming unit (CFU) number in rheumatoid arthritis (RA) patients and controls. (a) Representative photomicrograph of late-outgrowth CFUs in culture after 15 days from one RA patient ( $\times 40$ magnification). (b) Increase of CFU number in RA patients $(P<0.05)$. 
can be derived from peripheral blood depending on the different culture methods and times [24,28]. Although both EPCs express endothelial markers, they have different morphologies, patterns of growth, and angiogenic properties and thus might have different roles in neovasculogenesis [24,29-31]. Late-outgrowth EPCs that represent the progenitors with the more genuine endothelial properties such as tube-forming activity in vitro and in vivo need to be better characterized in the context of inflammatory conditions. Previously, the late EPC subpopulation has been studied in systemic sclerosis by our group and their endothelial properties confirmed by angiogenic tests [32]. As reported in systemic sclerosis, we observed that the RA patients, having high Lin-7AAD-CD $34^{+} \mathrm{CD} 133^{+} \mathrm{VEGFR}-2^{+}$, displayed a higher number of EPC-CFUs. However, the size of the sample reduced by the non-systematic achievement of EPCCFUs could explain the limited increase of EPC-CFU numbers in RA patients as well as the lack of association with disease activity and will need larger studies.

We thus assume that our EPC definition allows a wellcharacterized quantification of late-outgrowth EPCs. In RA, our data support the contribution of late-outgrowth EPCs to synovitis according to our finding of a strong link with disease activity. The direct correlation of EPC counts with DAS-28 levels is strengthened by the fact that RA patients in remission displayed EPC levels comparable to those of controls. Together with evidence of CD133/ VEGFR-2 $2^{+}$cells in RA synovial tissue [17], our results emphasize a key role for vasculogenesis and EPC mobilization in RA.

Preliminary data on CEC outcome in vascular diseases have suggested a relationship between the detachment of mature CECs and vascular hurting [33]. We concomitantly determined the value of CECs as compared with EPCs. We found a correlation in RA between these two circulating cell levels but CEC levels in RA did not differ for the ones in controls. Using a CD146 immunoselection in whole blood, one study found enhanced CEC levels but failed to identify a specific association with blood inflammatory markers [34]. The best combination of surface markers including exclusion of dead cells by viability marker seems to be required for CEC quantification.

One of the pitfalls of EPC quantification in RA is the potential involvement of atherosclerosis in EPC changes $[35,36]$. However, we excluded from our study individuals with classical cardiovascular risk factors and also those with previous clinical events. Furthermore, we did not find an increase of CEC levels in our RA population which reflects endothelial injury. Indeed, we presume that EPC increase relates to RA disease activity and synovial inflammation, although measurement of infra-clinical atheroma would be necessary to definitely rule out endothelial dysfunction.
We then attempted to correlate EPC counts with blood markers reflecting inflammation (ESR), endothelium injury (sVCAM), or synovial involvement (COMP and YKL-40). While we failed in the identification of any link, sVCAM, COMP, and YKL-40 were found to be increased in RA patients, thus confirming the activity of the disease in our sample of RA patients. We assume that, despite the lack of a link with serum markers, the identification of a relationship between EPCs and DAS-28 is highly relevant. EPC count is probably influenced by several factors, including inflammation, vascular injury, and potentially the immune response with bone marrow changes. The multifactorial regulation probably precludes the identification of a correlation with one single serum marker. Therefore, EPCs could represent a new 'integrative' biomarker. Its predictive value on disease outcome, including both articular and cardiovascular issues, will have to be evaluated in upcoming prospective studies.

\section{Conclusions}

We demonstrate enhanced levels of late-outgrowth EPCs in RA and a relationship with disease activity. This supports the implication of vasculogenesis in the perpetuation of the synovitis that occurs in RA. Late-outgrowth EPC isolation also offers a unique opportunity to determine an RA endothelial signature.

\section{Abbreviations}

7AAD: 7-aminoactinomycin D; CEC: circulating endothelial cell; CFU: colonyforming unit; COMP: cartilage oligomeric matrix protein; DAS-28: 28-joint disease activity score; EGM-2: endothelial growth medium; EPC: endothelial progenitor cell; ESR: erythrocyte sedimentation rate; FACS: fluorescence-activated cell sorting; KDR: kinase-insert domain receptor; Lin: lineage; PBMC: peripheral blood mononuclear cell; RA: rheumatoid arthritis; SDF-1: stromal-derived factor-1; sVCAM: soluble vascular cell adhesion molecule-1; TNF: tumor necrosis factor; VEGFR-2: vascular endothelial growth factor receptor-2; YKL-40: human cartilage glycoprotein-39.

\section{Competing interests}

The authors declare that they have no competing interests.

\section{Authors' contributions}

VJ contributed to the study design and did most of the experimental procedures and data analysis. JA, AP, and BR participated in some of the experimental procedures and the data analysis. YA recruited the patients, analyzed the results, and supervised the study. $A K, C B$, and $G U$ contributed to the revision of the manuscript. All authors read and approved the final manuscript.

\section{Acknowledgements}

This work was supported by an unrestricted grant from Wyeth (Paris, France). Wyeth did not have access to the data or to the writing of the manuscript.

\section{Author Details}

1INSERM U781, Paris Descartes University, Necker Hospital, 149 Rue de Sevres, 75015 Paris, France, 2Rheumatology A department, Cochin Hospital, APHP, 27 rue du faubourg Saint Jacques, 75014 Paris, France, ${ }^{3}$ UVSQ University,

Biochemistry, Hormonology and Molecular Genetics Department, Ambroise Paré Hospital, AP-HP, 9 avenue Charles-de-Gaulle, 92100 Boulogne-Billancourt, France and 4INSERM U972, Paul Brousse Hospital, 14 avenue Paul VaillantCouturier, BP200, 94804 Villejuif, France 
Received: 13 November 2010 Revisions Requested: 18 December 2009 Revised: 21 January 2009 Accepted: 16 February 2010

Published: 16 February 2010

\section{References}

1. Koch AE: Angiogenesis as a target in rheumatoid arthritis. Ann Rheum Dis 2003, 62 (Suppl 2):ii60-67.

2. Sivakumar B, Harry LE, Paleolog EM: Modulating angiogenesis: more vs less. JAMA 2004, 292:972-977.

3. Walsh DA, Wade M, Mapp PI, Blake DR: Focally regulated endothelial proliferation and cell death in human synovium. Am J Pathol 1998, 152:691-702.

4. FitzGerald O, Soden M, Yanni G, Robinson R, Bresnihan B: Morphometric analysis of blood vessels in synovial membranes obtained from clinically affected and unaffected knee joints of patients with rheumatoid arthritis. Ann Rheum Dis 1991, 50:792-796.

5. Muz B, Khan MN, Kiriakidis S, Paleolog EM: Hypoxia. The role of hypoxia and HIF-dependent signalling events in rheumatoid arthritis. Arthritis Res Ther 2009, 11:201.

6. Akhavani MA, Madden L, Buysschaert I, Sivakumar B, Kang N, Paleolog EM: Hypoxia upregulates angiogenesis and synovial cell migration in rheumatoid arthritis. Arthritis Res Ther 2009, 11:R64.

7. Urbich C, Dimmeler S: Endothelial progenitor cells: characterization and role in vascular biology. Circ Res 2004, 95:343-353.

8. Egan CG, Caporali F, Garcia-Gonzalez E, Galeazzi M, Sorrentino V: Endothelial progenitor cells and colony-forming units in rheumatoid arthritis: association with clinical characteristics. Rheumatology (Oxford) 2008, 47:1484-1488.

9. Grisar J, Aletaha D, Steiner CW, Kapral T, Steiner S, Seidinger D, Weigel G, Schwarzinger I, Wolozcszuk W, Steiner G, Smolen JS: Depletion of endothelial progenitor cells in the peripheral blood of patients with rheumatoid arthritis. Circulation 2005, 111:204-211.

10. Herbrig K, Haensel S, Oelschlaegel U, Pistrosch F, Foerster S, Passauer J: Endothelial dysfunction in patients with rheumatoid arthritis is associated with a reduced number and impaired function of endothelial progenitor cells. Ann Rheum Dis 2006, 65:157-163.

11. Ingram DA, Caplice NM, Yoder MC: Unresolved questions, changing definitions, and novel paradigms for defining endothelial progenitor cells. Blood 2005, 106:1525-1531.

12. Ingram DA, Mead LE, Tanaka H, Meade V, Fenoglio A, Mortell K, Pollok K, Ferkowicz MJ, Gilley D, Yoder MC: Identification of a novel hierarchy of endothelial progenitor cells using human peripheral and umbilical cord blood. Blood 2004, 104:2752-2760.

13. Hill JM, Zalos G, Halcox JP, Schenke WH, Waclawiw MA, Quyyumi AA, Finkel T: Circulating endothelial progenitor cells, vascular function, and cardiovascular risk. N Engl J Med 2003, 348:593-600.

14. Nolan DJ, Ciarrocchi A, Mellick AS, Jaggi JS, Bambino K, Gupta S, Heikamp E, McDevitt MR, Scheinberg DA, Benezra R, Mittal V: Bone marrowderived endothelial progenitor cells are a major determinant of nascent tumor neovascularization. Genes Dev 2007, 21:1546-1558.

15. Allanore Y, Batteux F, Avouac J, Assous N, Weill B, Kahan A: Levels of circulating endothelial progenitor cells in systemic sclerosis. Clin Exp Rheumatol 2007, 25:60-66.

16. Kuwana M, Okazaki Y, Yasuoka H, Kawakami Y, Ikeda Y: Defective vasculogenesis in systemic sclerosis. Lancet 2004, 364:603-610.

17. Ruger B, Giurea A, Wanivenhaus AH, Zehetgruber H, Hollemann D, Yanagida G, Groger M, Petzelbauer P, Smolen JS, Hoecker P, Fischer MB: Endothelial precursor cells in the synovial tissue of patients with rheumatoid arthritis and osteoarthritis. Arthritis Rheum 2004, 50:2157-2166

18. Silverman MD, Haas CS, Rad AM, Arbab AS, Koch AE: The role of vascular cell adhesion molecule 1/very late activation antigen 4 in endothelial progenitor cell recruitment to rheumatoid arthritis synovium. Arthritis Rheum 2007, 56:1817-1826.

19. Distler JH, Allanore Y, Avouac J, Giacomelli R, Guiducci S, Moritz F, Akhmetshina A, Walker UA, Gabrielli A, Muller-Ladner U, Tyndall A, Matucci-Cerinic M, Distler O: EULAR Scleroderma Trials and Research group statement and recommendations on endothelial precursor cells. Ann Rheum Dis 2009, 68:163-168.

20. Avouac J, Juin F, Wipff J, Couraud PO, Chiocchia G, Kahan A, Boileau C, Uzan G, Allanore Y: Circulating endothelial progenitor cells in systemic sclerosis: association with disease severity. Ann Rheum Dis 2008, 67:1455-1460.

21. Arnett FC, Edworthy SM, Bloch DA, Mcshane DJ, Fries JF, Cooper NS, Healey LA, Kaplan SR, Liang MH, Luthra HS, Medsger TA Jr, Mitchell DM, Neustadt DH, Pinals RS, Schaller JG, Sharp JT, Wilder RL, Hunder GG: The American Rheumatism Association 1987 revised criteria for the classification of rheumatoid arthritis. Arthritis Rheum 1988, 31:315-324

22. Llevadot J, Murasawa S, Kureishi Y, Uchida S, Masuda H, Kawamoto A, Walsh K, Isner JM, Asahara T: HMG-CoA reductase inhibitor mobilizes bone marrow--derived endothelial progenitor cells. J Clin Invest 2001, 108:399-405

23. Walter DH, Rittig K, Bahlmann FH, Kirchmair R, Silver M, Murayama T, Nishimura H, Losordo DW, Asahara T, Isner JM: Statin therapy accelerates reendothelialization: a novel effect involving mobilization and incorporation of bone marrow-derived endothelial progenitor cells. Circulation 2002, 105:3017-3024.

24. Lin Y, Weisdorf DJ, Solovey A, Hebbel RP: Origins of circulating endothelial cells and endothelial outgrowth from blood. $J$ Clin Invest 2000, 105:71-77.

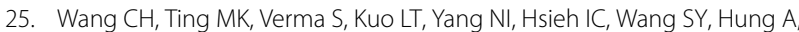
Cherng WJ: Pioglitazone increases the numbers and improves the functional capacity of endothelial progenitor cells in patients with diabetes mellitus. Am Heart J 2006, 152:1051.e1-1051.e8.

26. Scheubel RJ, Zorn H, Silber RE, Kuss O, Morawietz H, Holtz J, Simm A: Agedependent depression in circulating endothelial progenitor cells in patients undergoing coronary artery bypass grafting. J Am Coll Cardiol 2003, 42:2073-2080.

27. Werner N, Kosiol S, Schiegl T, Ahlers P, Walenta K, Link A, Bohm M, Nickenig G: Circulating endothelial progenitor cells and cardiovascular outcomes. NEngl J Med 2005, 353:999-1007.

28. Zhang Y, Ingram DA, Murphy MP, Saadatzadeh MR, Mead LE, Prater DN, Rehman J: Release of proinflammatory mediators and expression of proinflammatory adhesion molecules by endothelial progenitor cells. Am J Physiol Heart Circ Physiol 2009, 296:H1675-1682.

29. Mukai N, Akahori T, Komaki M, Li Q, Kanayasu-Toyoda T, Ishii-Watabe A, Kobayashi A, Yamaguchi T, Abe M, Amagasa T, Morita I: A comparison of the tube forming potentials of early and late endothelial progenitor cells. Exp Cell Res 2008, 314:430-440.

30. Gulati R, Jevremovic D, Peterson TE, Chatterjee S, Shah V, Vile RG, Simari RD: Diverse origin and function of cells with endothelial phenotype obtained from adult human blood. Circ Res 2003, 93:1023-1025.

31. Hur J, Yoon CH, Kim HS, Choi JH, Kang HJ, Hwang KK, Oh BH, Lee MM, Park YB: Characterization of two types of endothelial progenitor cells and their different contributions to neovasculogenesis. Arterioscler Thromb Vasc Biol 2004, 24:288-293.

32. Avouac J, Wipff J, Goldman O, Ruiz B, Couraud PO, Chiocchia G, Kahan A, Boileau C, Uzan G, Allanore Y: Angiogenesis in systemic sclerosis: impaired expression of vascular endothelial growth factor receptor 1 in endothelial progenitor-derived cells under hypoxic conditions. Arthritis Rheum 2008, 58:3550-3561.

33. Boos CJ, Blann AD, Lip GY: Assessment of endothelial damage/ dysfunction: a focus on circulating endothelial cells. Methods Mol Med 2007, 139:211-224.

34. Foster W, Shantsila E, Carruthers D, Lip GY, Blann AD: Circulating endothelial cells and rheumatoid arthritis: relationship with plasma markers of endothelial damage/dysfunction. Rheumatology (Oxford) 2009, 48:285-288.

35. Bacon PA, Raza K, Banks MJ, Townend J, Kitas GD: The role of endothelial cell dysfunction in the cardiovascular mortality of RA. Int Rev Immunol 2002, 21:1-17

36. Avouac J, Allanore Y: Cardiovascular risk in rheumatoid arthritis: effects of anti-TNF drugs. Expert Opin Pharmacother 2008, 9:1121-1128.

\section{doi: $10.1186 /$ ar2934}

Cite this article as: Jodon de Villeroché et al., Enhanced late-outgrowth circulating endothelial progenitor cell levels in rheumatoid arthritis and correlation with disease activity Arthritis Research \& Therapy 2010, 12:R27 